\title{
State Income Taxation of Out-of-State Trademark Holding Companies
}

\author{
Tun-Jen Chiang $\dagger$
}

In recent years, trademark holding companies have grown in popularity as a method of minimizing state income taxes. Typically, trademark holding companies are subsidiary companies incorporated in a state that does not levy income taxes upon royalty income. These companies are owned by parents operating in states that do tax such royalty income. The parent company is able to avoid taxation on its royalty income by transferring its trademarks to holding companies and licensing the trademarks back, thereby shifting the incomewhich would be taxed by the states in which it operates-to the trademark holding company.

Given the recent financial crises faced by the states, many states have sought ways to curb the effectiveness of trademark holding companies as a tax-avoidance device.' States have attempted to limit the ability of corporations to avoid taxes in three ways. The states have (1) directly taxed the out-of-state trademark holding company for income tax; (2) disallowed deductions to the parent corporation for royalty payments, making the parent unable to shift income out of the state; and (3) treated the parent and subsidiary as one unitary entity for income tax purposes, making intra-entity transfers of income meaningless. This Comment analyzes the Commerce Clause ${ }^{2}$ concerns raised by the various alternatives available to the states in closing this tax loophole.

Part I of the Comment outlines the general structure of trademark holding companies and their operation. Part II analyzes the first suggested solution, directly taxing out-of-state trademark holding companies. It concludes that this method of taxation is inconsistent with the dormant Commerce Clause, which requires a physical pres-

$\dagger$ B.Com., L.L.B. 2001, The University of Melbourne; J.D. Candidate 2004, The University of Chicago.

I See, for example, Virginia Young, Diverting Income Is Key to Game, St. Louis PostDispatch B1 (Sept 22, 2002) (discussing a proposal by the Missouri governor to close this tax loophole). By one calculation, corporate income taxes as a share of all state taxes have fallen from 10.2 percent in 1979 to 6.3 percent in 2000, though many factors contribute to this decline. See Michael Mazerov, Closing Three Common Corporate Income Tax Loopholes Could Raise Additional Revenue for Many States 1, online at http://www.cbpp.org/4-9-02sfp.pdf (visited Sept $18,2003)$.

2 US Const Art I, § 8, $\mathrm{cl} 3$. 
ence in the taxing jurisdiction. Part III analyzes the second and third methods of taxing trademark holding companies, both of which focus on the taxation of parent corporations. It argues that the second method, a simple denial of income tax deductions to parent corporations, violates the Commerce Clause's "fair apportionment" requirement, which prohibits measures that intrinsically produce double taxation on interstate commerce. And although the third solution-that states treat all parents and subsidiaries as unitary businesses for income tax purposes - is permissible under the Commerce Clause, it is excessive and unnecessarily costly to implement. Thus, Part III concludes that the most effective solution, consistent with the Commerce Clause, is a limited requirement that companies combine trademark income and expense reporting.

\section{AN OVERVIEW OF TRADEMARK HOLDING COMPANIES}

\section{A. Structure and Operation of Trademark Holding Companies}

Trademark holding companies are most commonly established in Delaware and Nevada, states that do not tax the income from trademark royalties, interest, or similar intangible income. The royalties paid to the trademark holding company by the parent are deductible and thus reduce the taxable income of the parent entity, but they are not taxed in the hands of the trademark holding company. In this way, the parent corporation avoids income tax liability while enjoying the advantages of doing business in the state levying the income tax. The royalty payment increases the value of the subsidiary trademark holding company, and the royalty is effectively returned to the parent corporation through the payment of dividends or capital appreciation.

If the sole purpose of the royalty arrangement were to avoid state income taxes, it would be regarded as a "sham transaction" and rendered ineffective." However, the utility of the "sham transaction" doctrine is limited in this context. Rarely would the trademark holding company serve no legitimate business purpose whatsoever. ${ }^{6}$ Corpora-

3 See Virginia Young, Committee Preserves Business Tax Breaks, St. Louis Post-Dispatch Al (May 15, 2002).

4 The amount of otherwise taxable income that is shifted through this device is difficult to estimate because much of the relevant information is confidential. As an example, however, one trademark holding company had an income of $\$ 55$ million in 1990 and paid no state income taxes. See Geoffrey, Inc v South Carolina Tax Commission, 313 SC 15, 437 SE2d 13, 15 n 1 (1993).

5 See, for example, Syms Corp v Commissioner of Revenue, 436 Mass 505, 765 NE2d 758, $762-63$ (2002) (describing the long-established state and federal tax practice of disregarding transactions that have no substantive or business purpose).

6 See, for example, Sherwin-Williams Co v Commissioner of Revenue, 438 Mass 71, 778 NE2d 504, 513-14, 517 (2002) (stating that a subsidiary trademark holding company was not a sham because it reinvested royalty income, did business with third parties, and paid expenses of maintaining trademark). 
tions can often plausibly claim that economies of scale justify having a subsidiary maintain and license its trademarks.

Thus, trademark holding companies present the problem that an incentive to avoid taxes by shifting income to corporations located in Nevada or Delaware is potentially accompanied by a legitimate business purpose. Whether a royalty fee has been artificially inflated to reduce income tax is difficult to determine-especially when (as often is the case) there is no external market for the trademark. In response, states have been forced to push the frontiers of their taxation powers in dealing with trademark holding companies.

\section{B. The States' Options in Seeking to Tax Trademark Holding Companies}

States aiming to tax the income represented by trademark royalties have several options. These options are broadly divided along two lines depending on whether the states are taxing the out-of-state holding company or the in-state parent.

First, states may attempt to tax the trademark holding company by expanding their tax jurisdiction to reach out-of-state companies with no physical presence (but an economic presence) in the state. This is the most aggressive approach, and it has been adopted by ten states through administrative or judicial holdings.'

Alternatively, states can attempt to effectively levy the same tax on the parent corporation operating within their borders. This can be done simply by denying deductions to income for royalty payments made to related companies, thereby preventing income from being transferred out-of-state through the trademark licensing device; five states have adopted this method. ${ }^{8}$ More comprehensively, the taxation of the parent can take the form of combined reporting, as is done by sixteen states. ${ }^{9}$ Combined reporting treats the parent and subsidiary as one entity for income tax purposes, making intra-entity transfers of income meaningless. Eighteen states have yet to do anything to combat the growing use of trademark holding companies to avoid income taxes.

7 These states are: Arkansas, Florida, Hawaii, Iowa, Maine, Massachusetts, New Jersey, North Carolina, South Carolina, and Wisconsin. See John J. Cronin and Maryann B. Gall, Economic Nexus: A Case Study, 14 State Tax Notes 535, 537-39 (1998) (collecting authorities).

8 These states are: Alabama, Connecticut, Mississippi, North Carolina, and Ohio. See Part III.A.

9 These states are: Alaska, Arizona, California, Colorado, Hawaii, Idaho, Illinois, Kansas, Maine, Minnesota, Montana, Nebraska, New Hampshire, North Dakota, Oregon, and Utah. See Mazerov, Closing Three Common Corporate Income Tax Loopholes at 8 (cited in note 1).

10 Four states, Connecticut, Kentucky, Missouri, and New Hampshire, have made argu- 


\section{The COMMERCE Clause AS A BARRIER TO DIRECTLY TAXING OUT-OF-STATE TRADEMARK HOLDING COMPANIES}

Directly taxing out-of-state trademark holding companies would treat such companies the same as any non-domiciliary company operating within the state. This approach has many advantages: it is the most effective method of preventing the use of trademark holding companies as a tax avoidance device; it requires little change in the income tax statutes of most states; it expands, rather than constrains, the existing tax powers of states; and it accurately taxes the income that is targeted. Any discussion of taxing trademark holding companies therefore must begin with an analysis of the availability of this method.

The strongest objection to the use of direct taxation of out-ofstate trademark holding companies is that it is forbidden by the dormant Commerce Clause. The Supreme Court has held that a company must have a "physical presence" in a state for the state to levy sales taxes on it." State courts, however, are divided over whether this physical presence requirement should be extended to cover income taxes as well. ${ }^{12}$ This Comment argues that the physical presence requirement does apply to income taxes, and that the dormant Commerce Clause therefore prevents the direct taxation of out-of-state trademark holding companies from being a viable solution for the states.

\section{A. The Physical Presence Requirement of the Dormant Commerce Clause}

The Supreme Court has long held that the Commerce Clause contains a dormant aspect that limits the power of states to regulate interstate commerce. ${ }^{13}$ This limitation extends to the state power of taxation over interstate commerce. ${ }^{14}$ Under modern Commerce Clause

ments for directly taxing out-of-state companies in tax audits, without adopting formal regulations. See Paul R. Comeau, Timothy P. Noonan, and Andrew B. Sabol, Intangibles Holding Companies: Life after Geoffrey 7, online at http:/www.hodgsonruss.com/files/holding.pdf (visited Sept 18, 2003). Four states, Nevada, South Dakota, Washington, and Wyoming, do not levy corporate income taxes and thus need no solution to this problem. See Mazerov, Closing Three Common Corporate Income Tax Loopholes at 2 table 1 (cited in note 1). Michigan does not have a corporate income tax, but its Single Business Tax has a profit component measured by the federal income tax due from the company. See Mich Comp Laws Ann $\S \S 208.3(3), 208.9(1)$ (West 1998).

11 Quill Corp v North Dakota, 504 US 298 (1992).

12 See text accompanying notes 30-34.

13 See South Carolina State Highway Department v Barnwell Brothers, Inc, 303 US 177, 185 (1938) (holding that state statutes that discriminate against interstate commerce are invalid under the Commerce Clause).

14 See Webber v Virginia, 103 US 344, 350-51 (1880) (invalidating, under the Commerce 
jurisprudence, state taxes levied upon interstate commerce must satisfy the four-part test developed in Complete Auto Transit, Inc $v$ Brady. ${ }^{15}$ This test requires that the tax: (1) be applied to an activity with a substantial nexus with the taxing state, (2) be fairly apportioned, (3) not discriminate against interstate commerce, and (4) be fairly related to the services provided by the state. ${ }^{16}$

Direct taxation of out-of-state trademark holding companies meets the latter three requirements. The taxation of income earned by the trademark holding companies from sales made to consumers (or parent corporations) in the taxing state is not likely to raise fair apportionment difficulties: A scheme where each state taxes the portion of net corporate income earned from consumers within its borders will not lead to multiple taxation. The income tax statutes concerned are generally applicable, not dependent on the crossing of state borders." Finally, the taxing state would almost certainly provide some services to the out-of-state trademark holding company to justify the tax, such as providing a forum to sue for breaches of contract and protecting the company's intangible property present in the taxing state. The only open Commerce Clause question is whether the trademark holding company has a "substantial nexus" with the taxing state.

The leading case on the substantial nexus prong of the Complete Auto test is Quill Corp v North Dakota. ${ }^{19}$ Quill Corporation, an out-ofstate mail order company, challenged the constitutionality of a North Dakota statute requiring the corporation to collect use taxes from sales to North Dakota consumers. ${ }^{20}$ While North Dakota had the power to levy its use tax on its own residents for their purchases from Quill, it remained unclear whether this taxing power allowed the state to require Quill to collect the tax for the transaction.

In National Bellas Hess, Inc v Department of Revenue of Illinois, ${ }^{21}$ a similar case twenty-five years earlier, the Court held that the lack of physical presence prevented the imposition of use tax collection upon out-of-state mail order companies under both the Due Process and

\footnotetext{
Clause, a Virginia statute requiring out-of-state manufacturer's sales representatives to pay a license tax).

15430 US 274 (1977).

16 Id at 279.

17 See Fulton Corp v Faulkner, 516 US 325, 331 (1996).

18 See Goldberg v Sweet, 488 US 252, 257 (1989).

19504 US 298 (1992).

20 A use tax is levied for the use or consumption of a good or service. Technically, it is levied upon the purchaser; however, the responsibility for collecting and paying the use tax generally lies with the seller. See, for example, ND Century Code $\$ 57-40.2-07$ (2002).

21386 US 753 (1967).
} 
Commerce Clauses of the Constitution. ${ }^{22}$ However, Bellas Hess was an old precedent, based on a discarded doctrine that forbade all direct burdens on interstate commerce. ${ }^{23}$

The Court in Quill affirmed Bella Hess's holding with respect to the Commerce Clause, but overruled its due process holding. With regard to the latter, the Court held that the evolution of due process doctrine after International Shoe Co $v$ Washington ${ }^{24}$ warranted the rejection of the rigid requirement of physical presence. Instead, the Court favored a more flexible inquiry into whether the company had sufficient "minimum contacts" with the taxing state. In line with its more recent due process decisions, such contacts could include the "continuous and widespread solicitation of business" within the taxing state so long as the collection of the tax did not offend "traditional notions of fair play and substantial justice.", ${ }^{, 25}$

However, the Court reaffirmed the holding of Bellas Hess with respect to the Commerce Clause. It distinguished the Commerce Clause from the Due Process Clause, arguing that the Commerce Clause concerned itself with the effects of state regulation on the national economy, whereas the Due Process Clause was concerned with individual fairness. ${ }^{26}$ The Court held that, though formalistic, "the bright-line rule of Bellas Hess furthers the ends of the dormant Commerce Clause" by creating a safe harbor from use and sales taxes "for vendors whose only connection with customers in the taxing State is by common carrier or the United States mail.,"27

The Quill Court did not decide whether its holding extended beyond sales and use taxes to income and other types of taxes that are at issue with trademark holding companies. The Court's opinion contains textual bases to argue both sides of this question. The Court stated that "in our cases subsequent to Bellas Hess and concerning other types of taxes we have not adopted a similar bright-line, physicalpresence requirement. ${ }^{, 28}$ On the other hand, the Court also cautioned, "Although we have not, in our review of other types of taxes, articulated the same physical-presence requirement that Bellas Hess estab-

22 Id at $758-60$.

23 See, for example, Leloup v Port of Mobile, 127 US 640, 648 (1888) ("[N]o State has the right to lay a tax on interstate commerce in any form."). The Supreme Court abandoned this test in Complete Auto and replaced it with the four-part test introduced earlier in this Comment. See text accompanying notes 14-15.

24326 US 310 (1945).

25 Quill, 504 US at 307-08.

26 Id at 312.

27 Id at 314-15.

28 Id at 317. 
lished for sales and use taxes, that silence does not imply repudiation of the Bellas Hess rule.",99

\section{B. Extending the Physical Presence Requirement to Limit Income Taxation of Out-of-State Companies}

State courts have split on whether Quill is limited only to sales and use taxes or applies also to income taxes. If Quill applies to income taxes, then states may not tax the out-of-state trademark holding companies that have no physical presence, rendering direct taxation of trademark holding companies unconstitutional.

Geoffrey, Inc $v$ South Carolina Tax Commission ${ }^{31}$ is the leading case in support of the view that Quill does not apply to income taxes. In Geoffrey, the South Carolina Supreme Court considered whether the state of South Carolina could tax a trademark holding company that, with no physical presence in South Carolina, was licensing trademarks to its parent operating in South Carolina. The court adopted a liberal conception of nexus, holding that the presence of intangible property generally is a sufficient nexus to levy income tax. ${ }^{31}$ It thereby held that the state could constitutionally tax the out-of-state trademark holding company. ${ }^{32}$

The Geoffrey opinion gave little consideration to Commerce Clause constraints, except to argue that the Quill Court did not explicitly encompass income taxes in its decision. Other state courts soon began to disagree with Geoffrey on this issue, arguing that though Quill involved a use tax, the underlying principle was nevertheless applicable to other types of taxes. ${ }^{33}$ Their argument was stated succinctly by the Tennessee Court of Appeals in J.C. Penney National Bank $v$ Johnson: $:^{34}$

While it is true that the Bellas Hess and Quill decisions focused on use taxes, we find no basis for concluding that the analysis

29 Id at 314

30313 SC 15, 437 SE2d 13 (1993).

31 Id at 18, citing International Harvester Co $v$ Wisconsin Department of Taxation, 322 US $435,441-42$ (1944) (holding that a state may constitutionally impose upon an in-state corporation the responsibility of collecting a tax on dividends to be distributed to stockholders, including those not residing in the taxing state).

32 Geoffrey, 437 SE2d at 16-17.

33 See, for example, Guardian Industries Corp v Department of Treasury, 18 Mich App 363, 499 NW2d 349, 356 (1993) ("[A]fter Quill, it is abundantly clear that [the taxpayer] must show a physical presence within a target state to establish a substantial nexus to it."). Compare $S Y L$ Inc $v$ Comptroller, 1999 Md Tax LEXIS 3 (Md Tax Ct 1999) (rejecting Geoffrey's substantial nexus analysis but declining to extend Quill to income taxes).

3419 SW3d 831 (Tenn Ct App 1999). 
should be different [for franchise and excise taxes].... Any constitutional distinctions between the franchise and excise taxes presented here and the use taxes contemplated in Bellas Hess and Quill are not within the purview of this court to discern. ${ }^{35}$

In order to uphold the taxation of trademark holding companies, there must be a legal distinction between use taxes and income taxes. There are two potential reasons to distinguish between the two taxes. The first would be if the Quill or Bellas Hess opinion articulated a legal distinction between the two taxes. The second would be that the two taxes have different economic effects. This section addresses these potential reasons and concludes that neither requires distinguishing use taxes from income taxes. Quill's physical presence requirement should apply to income taxes.

1. The economics of taxes.

A possible difference between income taxes and sales and use taxes may be drawn from international trade law, where economists have articulated a theoretical difference in the effects of income and sales taxes on trade, known as the "forward-shifting" theory. In the short run, if the seller is assumed to operate on a profit-maximizing strategy, a tax levied on income cannot affect the price or quantity of goods supplied because any changes in either will only reduce the taxable income further, and reduce the after-tax income as a result. That is, the only way to reduce the income tax payable is to reduce gross income, and for income taxes of less than 100 percent, this would also reduce the after-tax income of the seller. A sales or use tax levied on gross receipts, however, may be partly shifted to the consumer by increasing the price of the taxed item and reducing the quantity sold. Since the sales tax is levied on revenues and not profits, it is possible to reduce the tax payable by producing and selling fewer units, as this reduces taxable revenues. The combination of tax savings and cost savings (from reducing production) could be greater than the revenue losses from selling fewer units, making this economically rational for sellers. ${ }^{36}$ Since quantity sold decreases (and prices increase from reduced supply), interstate trade is decreased. Sales and use taxes are thus more effective in discouraging interstate trade in an item than are income taxes. Such reasoning would seem to justify a more stringent standard, such as a physical presence requirement, for the imposition of sales and use taxes on out-of-state companies.

35 Id at 839.

36 For a more detailed discussion of the forward-shifting theory in the context of international trade, see generally Kenneth W. Dam, The GATT Law and International Economic Organization 214-15 (Chicago 1970). 
In United States Glue Co v Oak Creek, ${ }^{37}$ the Supreme Court recognized this qualitative difference between taxes on net income and taxes on gross receipts, including sales and use taxes. The Court stated:

A tax upon gross receipts affects each transaction in proportion to its magnitude and irrespective of whether it is profitable or otherwise. Conceivably it may be sufficient to make the difference between profit and loss, or to so diminish the profit as to impede or discourage the conduct of the commerce. A tax upon the net profits has not the same deterrent effect, since it does not arise at all unless a gain is shown over and above expenses and losses, and the tax cannot be heavy unless the profits are large.

However, the economic difference between these two types of taxes is not so straightforward. First, the empirical evidence on the validity of the forward-shifting theory is inconclusive. While sales and use taxes, like other taxes on gross receipts (including tariffs), are likely to reduce quantity and increase price, studies suggest that income taxes may have a similar effect even in the short run. ${ }^{3 y}$ In any case, the lack of short-run shifting will lead to long-run declines in investment in the taxed entity as the return on capital declines as a result of the income tax."

Second, and more importantly, the argument made above for stricter limitations upon the ability of states to levy sales and use taxes because of their capacity to restrict trade considers only the effect of the tax on the quantity of interstate trade and not the distribution of the tax burden. Sales and use taxes are effective in changing quantity and price only because part of the burden may be shifted to consumers - the consumers of the taxing state. Income taxes, in contrast, cannot be so shifted if the forward-shifting theory holds true, and therefore the burden of the tax is borne fully by the out-of-state company. Since one goal of the dormant Commerce Clause is to ensure that each state taxes only its "fair share" of interstate commerce, the method of taxation that would be more effective in placing the burden on out-of-state companies should face stricter, not looser, scrutiny.

When the focus is placed on the distribution of the state tax, Oak Creek is distinguishable because it involved the taxation of an in-state

37247 US 321 (1918).

38 Id at 329.

39 See Marian Krzyzaniak and Richard A. Musgrave, The Shifting of the Corporation Income Tax: An Empirical Study of Its Short-Run Effect upon the Rate of Return $43-49$ (Johns Hopkins 1963) (presenting an empirical analysis of income tax shifting in manufacturing firms).

40 See id at $3-4$. 
company engaged in interstate commerce. At the time of Oak Creek, a state could not impose direct interference with the free flow of commerce, even upon its own domestic corporations. ${ }^{42}$ A sales or use tax burden is partly borne by the purchaser; an income tax burden is fully borne by the seller. A sales tax levied upon an in-state company for its sales to out-of-state customers would both reduce the quantity of interstate commerce and place part of the burden of the tax upon out-of-state consumers. An income tax, in contrast, would be fully borne by the in-state seller and have no effect on the price or quantity of interstate commerce. The situation is quite different in the case of out-of-state companies as in Bellas Hess or Quill: Although an income tax on out-of-state companies might not affect the amount of interstate commerce, the income tax is more likely to impermissibly transfer a state's tax burden onto out-of-state companies. Therefore, economic theory not only fails to support the Geoffrey principle as a basis for the distinction between income and sales taxes, it actually supports placing stringent limits on the income taxation of out-of-state companies. A physical presence requirement for income taxes is necessary to prevent states from shifting their tax burdens onto out-of-state companies. It is not as necessary for use taxes, because the taxing state's own consumers will end up bearing part of the burden of the use tax.

2. Stare decisis and reliance.

Historically, the Supreme Court has been hostile to sales and use taxes, and Bellas Hess was part of this tradition. ${ }^{44}$ Does stare decisis compel continued adherence to it only in the area of sales and use taxes? On this reading, the Court would not feel compelled to extend the physical presence requirement to a new area like income taxes. The remnants of the discredited but not discarded Bellas Hess doctrine would thereby create a distinction between the two types of taxes for the purposes of Quill.

The Quill Court noted this reliance argument when it observed that a substantial mail-order industry had developed due in part to the exemption from state taxation created in Bellas Hess. ${ }^{45}$ Justice Scalia suggested in a concurrence that this argument be taken even further:

41 See Oak Creek, 247 US at 325.

42 See Freeman v Hewit, 329 US 249, 255-56 (1946) (holding that a direct tax by a state on a seller in interstate commerce is invalid).

43 This assumes the forward-shifting theory holds. But if the theory does not hold, then there is no economic reason to distinguish between income and use taxes at all.

44 See General Motors Corp v Washington, 377 US 436, 439-40 (1964) (“[T]he Court has approved ... a net income tax on revenues derived from interstate commerce. . . However, local taxes measured by gross receipts from interstate commerce have not always fared as well."). See also Oak Creek, 247 US at 329.

45 Quill, 504 US at 316-17. 
It seems to me important that we retain our ability ... sometimes to adopt new principles for the resolution of new issues without abandoning clear holdings of the past that those principles contradict. ... [W]e ought not visit economic hardship upon those who took us at our word. ... It is my view, in short, that reliance upon a square, unabandoned holding of the Supreme Court is always justifiable reliance.

Thus, Bellas Hess created reliance by the mail-order industry on freedom from sales and use taxation, and this reliance compels the continued adherence to that precedent; but "new principles" would be applied to undecided areas like income taxation.

However, if stare decisis does compel adherence to Bellas Hess, the reliance interest cannot be based upon immaterial facts in the case, but could justifiably be extended to the logical implications of the holding in new areas, such as income taxation. Bellas Hess itself, as Justice White noted in his dissent in Quill, was substantially undermined in its reasoning by the subsequent decision of National Geographic Society $v$ California Board of Equalization. ${ }^{47}$ If the uncertainty over the continued vitality of the Bellas Hess doctrine did not already undermine the reliance interest of mail-order companies in Quill, why would the difference between sales and income taxes preclude reliance upon Quill by trademark holding companies? Unless there was some independent ground for distinguishing sales and income taxes that made the specific type of tax material to the analysis, merely defining the difference to be significant would be circular to the reliance reasoning.

But has the Supreme Court previously articulated a standard for income taxes that would preclude Quill from being extended to that field, making the difference between the two taxes legally significant? Geoffrey cites International Harvester Co $v$ Wisconsin Department of Taxation $^{48}$ as supporting its assertion that physical presence is not necessary to levy income taxes. ${ }^{49}$ But International Harvester is consistent

46 Id at 320-21 (Scalia concurring).

47430 US 551 (1977). In National Geographic, the Court wrote:

[T] he relevant constitutional test to establish the requisite nexus for requiring an out-ofstate seller to collect and pay the use tax is not whether the duty to collect the use tax relates to the seller's activities carried on within the State, but simply whether the facts demonstrate "some definite link, some minimum connection, between [the State and] the person it seeks to tax."

Id at 561, quoting Miller Bros v Maryland, 347 US 340, 344-45 (1954).

$48 \quad 322$ US 435 (1944).

49437 SE2d at 18. 
with a physical presence requirement because the tax on dividends in that case was imposed on a resident corporation. ${ }^{\text {s) }}$ The closest case that does support Geoffrey is Northwestern States Portland Cement Co $v$ Minnesota, ${ }^{\text {s1 }}$ which held, inter alia, that so long as the taxpayer has an adequate nexus with the taxing state, "net income from the interstate operations of a foreign corporation may be subjected to state taxation."' However, this holding was effectively overruled by Congress in Public Law 86-272, which created a physical presence rule for sales of tangible property. More importantly, while the Supreme Court has not defined a clear standard for nexus, what standard it does define is consistent with a physical presence requirement. ${ }^{.4}$ Both Portland Cement and Stockham Valves \& Fittings, the taxed companies in Northwestern, were physically present in their respective taxing states." $\mathrm{Be}$ fore Quill, the Supreme Court had not created any bright-line standard for the income taxation of out-of-state companies that would be incompatible with a physical presence rule.

\section{Administrative burden.}

The Bellas Hess Court based its reasoning partly on the administrative burden of a use tax on interstate commerce:

[I]f the power of Illinois to impose use tax burdens upon [an outof-state mail-order company] were upheld, the resulting impediments [on] interstate business would be neither imaginary nor remote. For if Illinois can impose such burdens, so can every other State, and ... every other political subdivision throughout the Nation.... The many variations ... could entangle [ ] interstate business in a virtual welter of complicated obligations to local jurisdictions with no legitimate claim to impose "a fair share of the cost of the local government."

50 See International Harvester, 322 US at 441 ("[W]e do not doubt that a state has constitutional power to make a levy upon a corporation, measured by so much of its earnings from within the state as it distributes in dividends, and to make the taxable event the corporation's relinquishment of the earnings to its stockholders.").

51358 US 450 (1959).

52 Id at 452 . See also id at 465 (noting that both tax statutes in question also satisfied the demands of the Due Process Clause).

53 Act of September 14, 1959, Pub L No 86-272, 73 Stat 555, codified as amended at 15 USC $\$ 381(2000)$.

54 See Northwestern, 358 US at 465 ("[A]lmost half of the corporation's income is derived from the taxing State's sales which are shown to be promoted by vigorous and continuous sales campaigns run through a central office located in the State.").

55 See id at 454-55.

56 Bellas Hess, 386 US at 759-60. 
The Court further noted that over 2,300 jurisdictions in the United States imposed sales or use taxes in 1965, a number that has subsequently grown to approximately $6,000 .{ }^{5.8}$ In contrast, very few local municipalities impose income taxes. ${ }^{59}$ Because more jurisdictions levy them, sales and use taxes create much higher administrative burdens than income taxes for companies operating in multiple states. The pragmatic argument is that the dormant Commerce Clause should therefore limit sales and use taxes more stringently than income taxes.

But while it is true that more jurisdictions currently levy sales and use taxes, no constitutional rule or natural imperative requires this to be the case. The effect of maintaining the formalistic distinction between sales taxes and income taxes, based solely on the number of jurisdictions that choose to levy one instead of the other, would be to punish those jurisdictions that choose to levy sales taxes. The doctrine would create a constitutionally mandated preference for income taxes, possibly inducing more jurisdictions to adopt them, even though these taxes increase the burden on out-of-state companies. Having stated a constitutional principle, the Court would have difficulty responding to an increase in the number of jurisdictions levying income taxes as jurisdictions seek to broaden their tax bases and shift their tax burdens onto out-of-state corporations through income taxes.

\section{Summary.}

The above analysis demonstrates that the J.C. Penney court was right that there should be no constitutional distinction between use taxes and other types of taxes-or at least not for income taxes on trademark holding companies. The direct taxation of out-of-state trademark holding companies offers a simple and effective remedy to the problem posed by such companies, but is legally indistinguishable from what was invalidated in Quill. States that wish to prevent the use of trademark holding companies to reduce income tax liability must, therefore, find some other method that comports with the requirements of the Commerce Clause.

57 Id at 759 n 12.

58 See Jerome R. Hellerstein and Walter Hellerstein, 1 State Taxation 9I 6.11[2] (Warren 3d ed 2001).

59 See id. 


\section{Federal Legislation to Authorize Taxation of Trademark Holding Companies}

Even if such taxation is prohibited by the Commerce Clause, states have one last option for directly taxing out-of-state companies: to seek federal legislation authorizing them to do so. As the Court noted in Quill, Congress has plenary power to regulate interstate commerce, including granting power to states that the Commerce Clause by itself denies." Congress could therefore legislate to allow states to levy income taxes directly on out-of-state trademark holding companies. However, present indications are that Congress is only likely to strengthen, not abrogate, the physical presence requirement for the levying of taxes by states.

The only legislation enacted in this area has been Public Law 86272 , which exempts the sale of tangible property from state income taxation where the only activity in the state is the solicitation of orders to be approved and shipped from outside of the taxing state. ${ }^{61}$ There are currently bills in Congress that would extend Public Law 86-272 to require a "substantial physical presence" before a state may levy a business activity tax. ${ }^{12}$ While the proposed statute does not define "substantial business activity," it does specifically exclude the presence of intangible property and the solicitation of contracts or orders for the sale of intangible property or services from constituting substantial physical presence. This would abrogate Geoffrey's holding.

The bills presently before Congress indicate that it is unlikely Congress will take action to overrule Quill, at least in the near future. States therefore must rely on devices that are both already available to them and consistent with the Commerce Clause.

\section{Alternative Methods To COMBAT TRADEMARK HOLDING COMPANIES}

If Geoffrey's approach of directly taxing the out-of-state trademark holding company is prohibited by the Commerce Clause, what may states do to capture the revenue that would be lost through this device? Two solutions are commonly proposed: denying deductions to parent corporations for trademark royalties paid to subsidiaries, and requiring the combined reporting of parent and subsidiary income. This Part argues that the denial of deductions for trademark royalties would be unconstitutional under the Commerce Clause on fair appor-

6) Quill, 504 US at 318.

61 See 15 USC $\S 381(2000)$. Obviously, this law does not protect trademark holding companies since the licensing of trademarks and the sale of technical assistance are sales of intangible property and services, respectively.

62 See HR 2526, 107th Cong, 1st Sess (2001); \$ 664, 107th Cong, 1st Sess (2001). 
tionment grounds, and the benefits of closing the trademark holding company loophole do not justify the cost of implementing combined reporting in all areas. It therefore advocates a remedy of combining only trademark-related revenues and expenses for state income tax purposes.

\section{A. Limiting the Deductibility of Royalty Payments}

Because trademark holding companies are effective only when their parent companies may deduct the royalty payments from their own incomes, limiting the deductibility of royalty payments will greatly curtail the effectiveness of trademark holding companies as an income tax avoidance device. Even though this narrow solution is less complete than the alternative of adopting combined reporting, it requires far less adjustment to the structure of the tax codes of most states. Five states, Alabama, ${ }^{63}$ Connecticut, ${ }^{64}$ Mississippi, ${ }^{65}$ North Carolina, ${ }^{60}$ and Ohio, have adopted this solution in some form. With the exception of Ohio, which enacted its statute in 1991, these states have only recently enacted these provisions.

The advantage of this solution is that it poses very few problems under the substantial nexus prong of the Complete Auto test, as articulated in Quill. ${ }^{\text {s. }}$ Although the Commerce Clause requires both a connection to the activity taxed and a connection to the actor, ${ }^{64}$ the power of the taxing state over the parent corporation, and over the profits earned by the parent corporation in the taxing state, is rarely in dispute.

The strongest objection to implementing denial of deductions in this form is a constitutional one. The scheme may violate the fair apportionment requirement of the Commerce Clause by effectively double-taxing the trademark holding company for its costs. To overcome this objection, this section argues that the denial of deductions to the parent for trademark royalties paid must also be accompanied by an allowance of deductions to the parent for trademark expenses

63 Ala Code $\$ 40-18-24$ (2001).

64 Conn Gen Stat $\$ 12-218 \mathrm{c}(2000)$ (restricting deductibility of intangible expenses incurred in transactions with related members).

652001 Miss Laws 586 (limiting deductions of intangible expenses incurred in transactions with related members).

66 NC Gen Stat $\S 105-130.7$ A (2001) (requiring royalties on payments to be added to net income).

67 Ohio Rev Code Ann $\$ 5733.042$ (Anderson 2002).

68504 US at 312-13.

69 Allied-Signal, Inc v Director, Division of Taxation, 504 US 768, 778 (1992) (stating that "there must be a connection to the activity itself" and not "only to the actor"). 
incurred by the subsidiary holding company. This effectively combines the parent and subsidiary into a unitary business for trademark purposes.

Two further objections may be made to this proposed solution. First, the Unitary Business Principle allows such a combination only if there is a "rational relationship" between the taxing state and the trademark holding company. Second, this solution is limited in scope, and does not reach other types of intra-entity transfers that divert income to lower-taxing states. This section argues that the combination of trademark holding companies and their parents will generally satisfy the requirements of the Unitary Business Principle. It concludes by considering the broader solution of combined reporting, but rejects it as unnecessary for the specific problem created by trademark holding companies.

\section{Fair apportionment.}

Because companies that operate in multiple states have revenues and costs that are not easily attributed to any particular state, ${ }^{70}$ these costs and revenues must be divided among the states for income tax purposes according to some apportionment formula. The fair apportionment requirement exists to "prohibit [apportionment formulas] that pass an unfair share of the tax burden onto interstate commerce." The Court has not required any particular method of apportionment. ${ }^{2}$ Rather, it examines the apportionment formula used for "internal" and "external" consistency.

The test for internal consistency is whether, if every jurisdiction applied the same apportionment formula, there would be double taxation. ${ }^{74}$ The test for external consistency is whether the apportionment formula actually reflects a reasonable sense of how income is generated:" States may not choose apportionment formulas that lead to taxation "out of all appropriate proportions to the business transacted ... in that State," or lead "to a grossly distorted result."

70) For example, the cost of the corporate headquarters cannot be said to contribute solely to the income earned in the state where the headquarters is located, but must be shared among the income from all the states where the corporation operates.

71 See Quill, 504 US at 313; Container Corp of America v Franchise Tax Board, 463 US 159, 169 (1983).

72 See Container Corp, 463 US at 164 (stating that "the Constitution imposes no single formula on the States").

73 Id at 169-70.

74 See id at 169.

75 See id.

76 Id at 170, quoting Hans Rees' Sons, Inc v North Carolina, 283 US 123, 135 (1931).

77 Container Corp, 463 US at 170, quoting Norfolk \& Western Railroad Co v State Tax Commission, 390 US 317,326 (1968). 
If every state denied deductions for all trademark royalties paid by the parent, and correspondingly excluded such royalties from the taxable income of the trademark holding company, the trademark holding company would be left with no taxable income against which to deduct its costs. This possibility violates the internal consistency requirement because it becomes possible that more than all of the income of the parent and subsidiary combined would be taxed. ${ }^{7 /}$ The denial of a deduction to the parent, without more, therefore violates the fair apportionment requirement.

To overcome the fair apportionment objection, therefore, a deduction must be allowed to the parent by reference to the trademark holding company's actual costs in creating and maintaining the trademark, apportioned by the same formula as that with which the income is taxed. So long as the tax is levied upon the in-state, parent corporation, the Quill limitation will not apply to prevent this tax.

This type of regime is currently most closely resembled by the Administrative Code of New York City. ${ }^{79}$ Under the New York City rules, combined filing is required where: (1) there is common ownership among the corporations; (2) the corporations and the proposed combined group are engaged in a unitary business; and (3) filing on a separate reporting basis distorts the taxpayer's income and tax liability. However, this provision has a loophole that limits its effectiveness: It requires combined filing only where separate reporting distorts the taxpayer's income. ${ }^{\mathrm{x} / 1}$ Given that the creation of a trademark holding company is usually accompanied by mixed motives, rarely does the company exist only to distort the taxable income of its parent. To effectively limit the trademark holding company's ability to exploit the tax loophole created by separate accounting of subsidiaries, the presumption should be reversed: Combined filing would be required

78 See Container Corp, 463 US at 169. To take a simplified example: Suppose the parent corporation had total revenues of $\$ 100, \$ 90$ of its own costs, and the subsidiary trademark holding company had $\$ 10$ of costs from maintaining the trademark, with no other income. The net profit of the unitary business of the parent and subsidiary combined would be zero. If the parent paid $\$ 10$ of royalties to the trademark holding company, the denial of the deduction for royalties would create a taxable income of $\$ 10$ for the parent corporation, and a deductible loss of $\$ 10$ for the trademark holding company. But if all jurisdictions denied a deduction for royalty payments. the trademark holding company would never have any income against which to deduct this loss, and the deduction would be wasted. The unitary business would pay taxes on $\$ 10$ of income when real income was zero.

79 See NYC Admin Code $\$ 11-605.4$ (2001).

80 The weakness of New York City's rule is exposed by the fact that, in a separate case in New York, Toys "R" Us was able to prevail on a claim that filing separately from Geoffrey (Toys "R" Us's trademark holding company) did not distort its tax liability. In the Matter of the Petition of Toys "R" US-NYTEX, Inc, 1999 NY City Tax LEXIS 31 (NYC Tax Apps Trib). 
unless the taxpayer could prove that separate reporting does not distort income. Alternatively, the presumption against the taxpayer could be made irrebuttable, and a deduction allowed only to the extent of the trademark holding company's actual trademark-related costs. This more stringent method would prevent abuse, as the company would have to prove not only a general lack of distortion, but would also have to specify affirmatively the expenses that are legitimately entitled to a deduction.

Because such a regime effectively combines the parent and subsidiary for the purpose of taxing trademark royalties, it could not be argued that the tax is on the parent's in-state activities alone. In cases where the parent corporation is not domiciled in the taxing state, to include the subsidiary trademark holding company's out-of-state costs requires that the subsidiary and the parent be treated as parts of a single unitary business. The Unitary Business Principle places limits on when this may be done.

\section{The Unitary Business Principle.}

The Unitary Business Principle is the "linchpin" of the fair apportionment test." Even though states have the power to provide their own definition of "income" for their income taxes, the Complete Auto test requires that there must nevertheless be "a rational relationship between the income attributed to the [taxing] State and the intrastate value of the enterprise.", Are the incomes of trademark holding companies placed beyond state tax powers, even via their in-state parents, for lack of any "rational relationship"?

Almost all trademark holding companies, if they conducted any significant amount of licensing to their parent corporations, would satisfy the requirements of unitary business. ${ }^{\mathrm{k}}$ In Container Corp of America $v$ Franchise Tax Board, the Supreme Court considered contacts including the provision of "advice and consultation regarding manufacturing techniques, engineering, design, architecture, insurance, and cost accounting to a number of its subsidiaries, either by entering into technical service agreements with them or by informal arrangement" as sufficient to establish a unitary business." Only a trademark holding

81 ASARCO Inc v Idaho State Tax Commission, 458 US 307,317 (1982).

82 Mobil Oil Corp $v$ Commissioner of Taxes of Vermont, 445 US 425, 437 (1980). See also International Harvester, 322 US at 441 ("In determining whether a tax is within the state's constitutional power, we look to the incidence of the tax and its practical operation, and not its characterization by state courts.").

83 The factors to be considered are (1) functional integration; (2) centralization of management; and (3) economies of scale. Allied-Signal, 504 US at 781 .

84463 US 159 (1983).

85 Id at 173. 
company that did extensive licensing to third parties would have a credible argument for protection under the Unitary Business Principle. Such companies would likely be bona fide discrete business enterprises and would not raise the same tax avoidance concerns as holding companies that licensed trademarks to parent companies where the royalty is not subject to market comparisons.

\section{Summary.}

The denial of a deduction for royalty expenses paid to related companies, with the necessary allowance of a substitute deduction for the related company's actual costs, should be an effective and uncomplicated method of preventing the avoidance of taxation through trademark holding companies while preserving their economic benefits, such as economies of scale through centralization. While this solution will not remove all possible loopholes arising from related party transactions, it will address the particularly prevalent form taken in trademark holding companies. If one's only concern is to target trademark holding companies, this is a more narrowly tailored solution that will effectively tackle the problem.

The incompleteness of this solution is an unavoidable consequence of its relative simplicity. To eliminate the underlying problem of related-party transactions, the combination of revenues and expenses would be extended beyond trademark activities. Such a remedy becomes combined reporting-a more comprehensive, but also more complicated and costly reform of state income tax laws.

\section{B. Combined Reporting}

Sixteen states use a combined reporting system. ${ }^{\text {gh }}$ The state levies tax on a pro rata share of all the income of a corporation and all its subsidiaries according to an apportionment formula, as opposed to the practice of taxing each company separately. Provided that the trademark holding company qualifies as part of the unitary business, which is required for any taxation regardless of the Quill limitation, transfers of income between different parts of the unitary business do not have any effect on tax liability.

The Supreme Court has ruled that combined reporting does not offend the substantial nexus requirement of Quill and Bellas Hess. Though combined reporting determines the tax payable by reference

86 Alaska, Arizona, California, Colorado, Hawaii, Idaho, Illinois, Kansas, Maine, Minnesota, Montana, Nebraska, New Hampshire, North Dakota, Oregon, and Utah. See Mazerov, Closing Three Common Corporate Income Tax Loopholes at 8 (cited in note 1). 
to the income of subsidiaries who have no physical presence in the taxing state, the ultimate tax liability lies with the in-state, physically present part of the unitary business."

Combined reporting is a comprehensive system that removes tax incentives to shift income within the corporate structure, yet allows such transfers where they result in economic benefits. It is therefore generally favored by academics. Its expansion of the definition of the taxable entity to include affiliates that would otherwise be beyond the taxing jurisdiction of the state creates hostility from business, which generally faces higher tax bills as a result."

A stronger objection, however, is that to create a combined reporting system requires substantial modification to the existing tax regime, entailing significant administrative costs in making such a transition. For the single problem posed by trademark holding companies, the drastic change to combined reporting for all businesses does not seem to be cost justified. ${ }^{\text {. }}$ Combined reporting does offer additional benefits such as reaching a broader set of transactions between related entities, but whether states might otherwise choose to adopt combined reporting for these additional benefits is beyond the scope of this Comment."

87 See Barclays Bank v Franchise Tax Board of California, 512 US 298, 311 n 10 (1994) (internal citations omitted):

Quill held that the Commerce Clause requires a taxpayer's "physical presence" in the taxing jurisdiction [California] before that jurisdiction can constitutionally impose a use tax. The California presence of the taxpayers before us is undisputed, and we find nothing in Quill to suggest that California may not reference the income of corporations worldwide with whom those taxpayers are closely intertwined in order to approximate the taxpayers' California income.

x8 See, for example, Michael J. McIntyre, Paull Mines, and Richard D. Pomp, Designing a Combined Reporting Regime for a State Corporate Income Tax: A Case Study of Louisiana, $61 \mathrm{La}$ L $\operatorname{Rev} 699,700$ (2001) (suggesting a method for Louisiana to change its corporate tax structure to require that multistate corporations use combined reporting).

89 See, for example, Barclays Bank, 512 US at 307, 309 \& n 8 (showing increased tax liability under a combined reporting system). See also Avrum D. Lank and Steven Walters, Tax on Profits Has No Teeth, Milwaukee J Sentinel 1A (Apr 14, 2002) (reporting business opposition to combined reporting in Wisconsin).

9) This is, of course, an empirical question. Proponents of closing the trademark holding company loophole have estimated the additional revenue accruing to some states to be in excess of $\$ 100$ million annually. See, for example, Jay Hancock, Maryland Needs to Close Out-of-State Tax Loophole, Baltimore Sun 1D (Feb 5, 2003). Others have given estimates as low as $\$ 5$ million. See Young, Diverting Income, St. Louis Post-Dispatch at B1 (cited in note 1). In any case, these estimates do not consider the limited incremental benefit of adopting combined reporting for all business operations over the cheaper remedy that this Comment advocates.

91 Another possible solution that this Comment has not considered is that instead of levying an income tax, a state could levy a use tax on all trademark and intangible purchases, payable by the in-state parent corporation. As long as such a tax is applied equally to intrastate licensing of trademarks, it is unlikely to run afoul of the Commerce Clause's non-discrimination requirement. However, this would levy both an income tax and a use tax on trademarks. The disadvantage of such a solution would be that it creates an economic distortion in the make-or-buy deci- 


\section{CONCLUSION}

Trademark holding companies have become a popular form of tax avoidance. While states are under no obligation to tax these entities, ${ }^{\text {"n }}$ the ability to avoid income tax while enjoying the benefits of doing business in a state poses a grave revenue concern for the states. This Comment has explored various methods to close this tax loophole.

While some academic commentary and ten states have seen direct taxation as the best solution to the problem posed by trademark holding companies, Supreme Court precedent in Quill dictates that the solution be found elsewhere. Physical presence of the taxed entity is a bright-line rule that the Court has refused to abandon and Congress is only likely to reinforce; but there is no reason why the line should not be drawn around both income and sales taxes. If the reaffirmance of Bellas Hess in Quill was dictated by formalism, its extension to income taxes is required for consistency in reasoning.

Operating under the constraints of physical presence, the only solution is for states to tax the parent corporation instead. A full combined reporting system for all corporate income tax would not be an economical solution to this problem. The cheaper option of denying deductions to parent corporations would overtax companies for legitimate trademark maintenance expenses and violate fair apportionment. Combining the parent and subsidiary only for trademark revenues and costs is the most effective solution, eliminating trademark holding companies as a tax avoidance device, while avoiding the cost of a full transition to combined reporting.

sion: Companies that license trademarks for legitimate business purposes must pay the use tax, while companies developing trademarks in-house do not.

92 In fact, they may not wish to: Multi-jurisdictional corporations that set up these tax avoidance devices may be more likely to be sensitive to tax rates and have the option of moving elsewhere. 


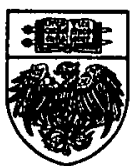

